\title{
Cross-shelf distributions and recruitment of crab postlarvae in a region of strong upwelling
}

\author{
Steven G. Morgan ${ }^{1,2,}{ }^{*}$, Jennifer L. Fisher ${ }^{1}$, Amber J. Mace ${ }^{1,5}$, Leah Akins ${ }^{1,6}$, \\ Anne M. Slaughter ${ }^{3}$, Stephen M. Bollens ${ }^{4}$ \\ ${ }^{1}$ Bodega Marine Laboratory, University of California Davis, 2099 Westside Drive, Bodega Bay, California 94923-0247, USA \\ ${ }^{2}$ Department of Environmental Science and Policy, University of California Davis, 1 Shields Avenue, Davis, California 93510, USA \\ ${ }^{3}$ Romberg-Tiburon Center for Environmental Studies, San Francisco State University, Tiburon, California 94920, USA \\ ${ }^{4}$ School of Earth and Environmental Sciences, Washington State University, Vancouver, Washington 98686-9600, USA \\ ${ }^{5}$ Present address: California Ocean Science Trust, 1330 Broadway, Suite 1135, Oakland, California 94612-2530, USA \\ ${ }^{6}$ Present address: New York State Department of State, Division of Coastal Resources, 99 Washington Avenue, Albany, \\ New York 12231, USA
}

\begin{abstract}
Larvae are thought to be highly vulnerable to offshore transport in productive upwelling regions, which increases cross-shelf and alongshore dispersal, limits recruitment, and reduces the strength of community interactions. We investigated whether the last planktonic stages of shallowwater crabs (1) occur far offshore during the peak upwelling season in a region of strong upwelling that is recruitment limited, (2) occur farther offshore during upwelling than relaxation conditions, (3) occur farthest from shore at a major headland where currents are deflected offshore, and (4) recruit less during years of stronger upwelling. Crab postlarvae were collected from between 1 and $70 \mathrm{~km}$ from shore at 3 locations across an upwelling cell during upwelling and relaxation conditions in northern California, USA, for $3 \mathrm{yr}$, and recruitment was measured at 2 sites during 2 of these years. Postlarvae of all species collected were most abundant on the inner continental shelf $(84 \%)$ and were scarce in the open ocean. Postlarvae of 3 taxa only occurred on the inner shelf, whereas postlarvae of the other 3 taxa collected occurred in low abundances on the outer shelf even during prolonged upwelling. They were abundant close to shore at the Point Reyes headland where flow is deflected offshore. Postlarvae did not occur farther from shore during a year of very strong upwelling, and 4 of 7 taxa recruited more then. Thus, crab postlarvae do not appear to be advected far offshore or recruit less during strong upwelling conditions, and the cause and extent of recruitment limitation warrants further investigation.
\end{abstract}

KEY WORDS: Recruitment limitation $\cdot$ Larval transport $\cdot$ Population dynamics $\cdot$ Community interactions $\cdot$ Migration $\cdot$ Dispersal $\cdot$ Upwelling

Resale or republication not permitted without written consent of the publisher

\section{INTRODUCTION}

The recruitment of propagules is a key determinant of the dynamics and structure of populations and communities and has been a central focus of ecological studies for over a century. Nevertheless, the role of recruitment in determining population dynamics and community structure in the sea is still not well understood due to fundamental differences in the life cycles of typical marine and terrestrial organisms (Morgan
2001, Carr et al. 2003). It is extremely difficult to determine the source and fate of marine organisms with planktonic larvae, because they spend weeks developing in oceanic currents that may transport them far from natal populations (Thorson 1950, Scheltema 1975, Morgan 1995). Fisheries biologists began attributing wide fluctuations in year class strength to variation in larval loss long ago (Hjort 1914), and decades of research have shown that stock-recruitment relationships are notoriously poor (Frank \& Leggett 1994). Until compar- 
atively recently, marine ecologists have focused on interspecific interactions during the adult phase of the life cycle, and interest in the larval phase has largely been limited to larval settlement, the last moments of larval life (Morgan 2001, Underwood \& Keough 2001). A resurgence of interest in recruit-stock relationships by benthic ecologists has led to the recognition that abundant recruitment generates intense post-settlement interactions and high mortality, whereas little recruitment leads to weaker interactions, lower mortality, and the persistence of cohorts of recruits in populations (Morgan 2001, Underwood \& Keough 2001). However, oceanographic conditions determining the large temporal and spatial variation in larval supply are not well understood and are becoming a focal point of investigation by marine ecologists (Young 1990, Morgan 2001, Underwood \& Keough 2001).

Temporal and spatial variation in reproductive timing and subsequent larval settlement is now thought to be determined by larvae being swept far offshore in upwelling regions, thereby limiting their ability to return to replenish adult populations nearshore (Parrish et al. 1981, Yoshioka 1982, Roughgarden et al. 1988). Strong prevailing winds, combined with the Coriolis effect, transport larvae in surface waters toward the equator and far offshore via Ekman transport, while cold, nutrient-rich bottom waters upwell along the shore, generating high productivity and some of the world's most productive fisheries (Hickey 1998, Kirincich et al. 2005). Compelling evidence has been provided that larvae of an intertidal barnacle are swept far off the coast during periods of strong upwelling, limiting the number of recruits to coastal communities and subsequent interactions among them (Gaines \& Roughgarden 1985, Roughgarden et al. 1988). Larvae were advected far from shore during years of strong upwelling, limiting recruitment to infrequent relaxations of prevailing upwelling winds (Roughgarden et al. 1988, Farrell et al. 1991). Larvae occurred shoreward of an 'upwelling front' that may form between cold upwelled water nearshore and warmer water offshore, and the distance of this front from shore was proposed as a good indicator of recruitment in time and space (Roughgarden et al. 1988, 1992, Farrell et al. 1991, Grantham 1997). Many key insights into the ecology of marine communities sprang from conducting small-scale manipulative experiments of adults on these shores, and the recognition that oceanographic forcing could account for much of the unexplained temporal and geographic variation in larval recruitment was highly influential in refocusing the direction of the field (Young 1990, Morgan 2001, Underwood \& Keough 2001).

Stronger, more persistent upwelling in central and northern California than in the Pacific Northwest and southern California (Parrish et al. 1981, Hickey 1998,
Kirincich et al. 2005) may reduce settlement and the intensity of benthic interactions for invertebrates on the rocky shore (Connolly et al. 2001, Menge et al. 2004). Similar results have been obtained across large spatial scales in upwelling regions elsewhere in the world (Broitman et al. 2001, Hutchings et al. 2002, Menge et al. 2003, Rilov \& Schiel 2006). Upwelling intensity also varies within regions and partially explains mesoscale variability in larval density patterns along the shoreline. For example, upwelling is strongest at headlands where alongshore flow is deflected far offshore transporting larvae with it and limiting recruitment (Ebert \& Russell 1988, Lagos et al. 2005, Kaplan \& Largier 2006, Roughan et al. 2006). An eddy may form in the lee of headlands that concentrates larvae in high abundance (Wing et al. 1995, 1998, Mace \& Morgan 2006a). During relaxation events, larvae are transported poleward from these retention areas by alongshore currents (Wing et al. 1995, 2003). Thus, larval retention is thought to occur only in the lee of headlands, and recruitment elsewhere is limited to infrequent relaxation events.

It is also becoming increasingly apparent that larvae may remain closer to parental populations than previously believed (Strathmann et al. 2002). Larvae of some coastal species remain close to shore throughout development while others migrate various distances offshore (Queiroga \& Blanton 2005, Morgan 2006). These interspecific differences in cross-shelf migrations are behaviorally mediated by the timing, duration, and amplitude of vertical migrations around the mean depth of larvae relative to seaward-flowing surface waters and landward-flowing bottom waters (Queiroga \& Blanton 2005, Morgan 2006). Characteristic circulation of upwelling regions may contribute to the passive retention of larvae nearshore while also enabling behavioral regulation of transport (Peterson et al. 1979, Grantham 1997, Shanks \& Eckert 2005, Papastephanou et al. 2006, Morgan et al. 2009). A coastal boundary layer of weaker cross-shelf and alongshore flow coupled with depth regulation in opposing stratified currents may play a role in keeping crab larvae close to shore. Larvae that remain beneath the shallow Ekman layer nearshore are expected to be advected slowly onshore and alongshore (Largier et al. 1993, Peterson 1998, Kirincich et al. 2005). Larvae resist being carried to the surface in upwelled waters and are trapped in an onshore flow convergence near the coast (Genin et al. 2005, Shanks \& Brink 2005). Ontogenetic changes in vertical distribution enable other species to migrate beyond the coastal boundary layer. Early larval stages of some species occur in the Ekman layer, transporting them offshore and equatorward, whereas later larval stages occur at depth, advecting them onshore and poleward (Grantham 
1997, Peterson 1998, Queiroga et al. 2005, Shanks \& Eckert 2005, Papastephanou et al. 2006, Morgan et al. 2009). Postlarvae also are delivered onshore by internal waves and wind relaxations or reversals (Pineda 1995, Shanks 1995, Grantham 1997, Wing et al. 2003). Diel vertical migrations between the 2-layered flow also can keep larvae in the coastal boundary layer and on the continental shelf, depending on the species (Peterson 1998, Batchelder et al. 2002, Marta-Almeida et al. 2006, dos Santos et al. 2008). Thus, the effect of ocean conditions on larval settlement and benthic interactions could vary considerably among rocky shore species depending on the extent of their crossshelf larval migrations.

We tested the hypotheses that postlarvae of shallowwater species of crabs (1) occur on the outer shelf or in the open ocean rather than on the inner shelf during the peak upwelling season in a region of strong upwelling that is recruitment limited, (2) occur farther offshore during upwelling than during relaxation conditions, (3) occur farthest from shore at major headlands where currents are deflected offshore, and (4) recruit less during years of stronger upwelling. Alternatively, if larval behavior effectively regulates cross-shelf transport and recruitment, then some species should occur only close to shore while other species occur farther offshore, even during upwelling conditions, at headlands and during years of strong upwelling. Recruitment also should not be diminished by strong upwelling. To provide a robust test of these hypotheses, we determined the cross-shelf distributions of crab postlarvae (last planktonic stage, also known as megalopae) and recruitment for consecutive years during the peak upwelling season in a region of strong upwelling that is recruitment limited.

\section{MATERIALS AND METHODS}

Study system. The study was conducted in the upwelling cell between Point Reyes and Point Arena in northern California (Fig. 1), at the windiest place along the west coast of the USA (Koracin et al. 2004). Crabs in this region spend weeks to months developing in the plankton. Anomuran (Porcellanidae, Paguroidea) and brachyuran crabs (Cancridae, Majidae, Pinnotheridae, Grapsidae) commonly recruit onshore after developing through 2 to 5 larval stages and a postlarval stage before returning to the benthos as juveniles (Morris et al. 1980, Wing et al. 1995, Mace \& Morgan 2006a, S. G. Morgan et al. unpubl.). Adult porcellanids and grapsids are restricted to shallow waters, whereas adult cancrids, majids, pinnotherids, and pagurids primarily reside on the inner shelf with some species ranging to the outer shelf or slope (Morris et al. 1980).
Cancrids along the California coast release larvae between December and March (Reilly 1983, Strathmann 1987), during seasonal strong winds from storm events and a weakly poleward nearshore flow (Hickey 1998). They spend the next 1 to 6 mo developing in the plankton, depending on the species (Reilly 1983, Strathmann 1987, Grantham et al. 2003, Shanks \& Eckert 2005). Peak settlement occurs in April and May after nearshore flow shifts equatorward and upwelling conditions prevail (Largier et al. 1993, Hickey 1998, Roughan et al. 2006). The other crabs spend only about 1 to 2 mo in the plankton and settle primarily from May to August (Grantham et al. 2003, Shanks \& Eckert 2005, Mace \& Morgan 2006a).

The cross-shelf distributions of crab larvae have not been determined in our region but have been described off the coast of Oregon (Lough 1974). Little has been published on their vertical distributions, although it was recently found that $98 \%$ of larvae and postlarvae of 45 species occur $<50 \mathrm{~m}$ deep in the surface mixed layer (Morgan et al. 2009). Postlarvae of several species of majids and grapsids occur in the neuston in surface convergences, and postlarvae of several species of cancrids occur $<5 \mathrm{~m}$ deep, where they could be transported onshore by winds and internal waves (Shenker 1988, Hobbs \& Botsford 1992, Shanks 2006).

Larval distributions. Crab postlarvae were collected throughout the water column along 3 cross-shelf transects consisting of 18 stations that were sampled during the Wind Events and Shelf Transport (WEST) cruises (Fig. 1, Table 1). Transects spanned most of the upwelling cell between Point Arena and Point Reyes and extended 1 to $70 \mathrm{~km}$ from shore, well beyond the shelf break ( $\sim 30 \mathrm{~km}$ offshore). Eight cruises were conducted between mid-May and mid-June during upwelling and relaxation conditions for $3 \mathrm{yr}$ (2000 to 2002). The ship was scheduled well in advance of cruises, precluding adaptive sampling to target brief, infrequent relaxation events. Offshore sea surface temperature and wind speed and direction were obtained from the National Data Buoy Center (NDBC $46013,38^{\circ} 13^{\prime} 30^{\prime \prime} \mathrm{N}, 123^{\circ} 19^{\prime} 00^{\prime \prime} \mathrm{W}$ ), and the wind data were rotated in the alongshore direction to a principal axis of $349.4^{\circ}$ (Dever et al. 2006). Upwelling events were characterized by $36 \mathrm{~h}$ low-pass-filtered equatorward wind speeds greater than $5 \mathrm{~m} \mathrm{~s}^{-1}$ and cold sea surface temperatures, and relaxation conditions occurred when wind speeds were less than $3 \mathrm{~m} \mathrm{~s}^{-1}$ and surface temperatures were warm.

Five cruises were conducted during upwelling conditions, and 3 cruises were conducted during relaxation events (Table 1). Two cruises were conducted in 2000, and both were conducted during relaxation conditions. The first cruise followed 2 wk of strong 
upwelling at the onset of relaxation (2 to 5 June). The second cruise occurred after $3 \mathrm{~d}$ of relaxation and before upwelling returned (17 to 20 June). Three cruises occurred in 2001: 2 during upwelling and 1 during relaxation conditions. The first cruise (19 to 24 May) followed $4 \mathrm{~d}$ of strong upwelling and coincided with $3 \mathrm{~d}$ of relaxation and $2 \mathrm{~d}$ of upwelling. The second ( 3 to 10 June) and third (11 to 14 June) cruises were conducted during prolonged upwelling conditions following $2 \mathrm{~d}$ and $10 \mathrm{~d}$ of upwelling, respectively. All 3 cruises in 2002 were conducted during prolonged upwelling conditions following $3 \mathrm{~d}$ (31 May to 1 June), $9 \mathrm{~d}$ ( 7 to 9 June), and $2 \mathrm{~d}$ (15 to 17 June) of upwelling. Stations were sometimes skipped due to logistical difficulties and inclement weather. Overall, more stations were sampled during prevailing upwelling (52) than relaxation (38) conditions and off Bodega Bay (37) and Point Reyes (31) than Salt Point (22). Similar numbers of stations were sampled each year (2000: 27; 2001: 32; 2002: 31) and time of day (day: 47; night: 43). The percentage of samples taken during the daytime was as follows: $68 \%$ during upwelling and $32 \%$ during relaxation; $27 \%$ off Salt Point, $43 \%$ off Bodega Bay, and $30 \%$ off Point Reyes; and $25 \%$ in 2000, $36 \%$ in 2001, and $39 \%$ in 2002 .

The vertical distributions of crab postlarvae are not well known along the West Coast, and therefore plankton was sampled through most of the water column at each station to ensure capture. Paired bongo nets $(0.6 \mathrm{~m}$ net diameter, $335 \mu \mathrm{m}$ and $500 \mu \mathrm{m}$ mesh) were towed obliquely from either $5 \mathrm{~m}$ off the bottom or $200 \mathrm{~m}$ depth to the surface. The depth of the net above
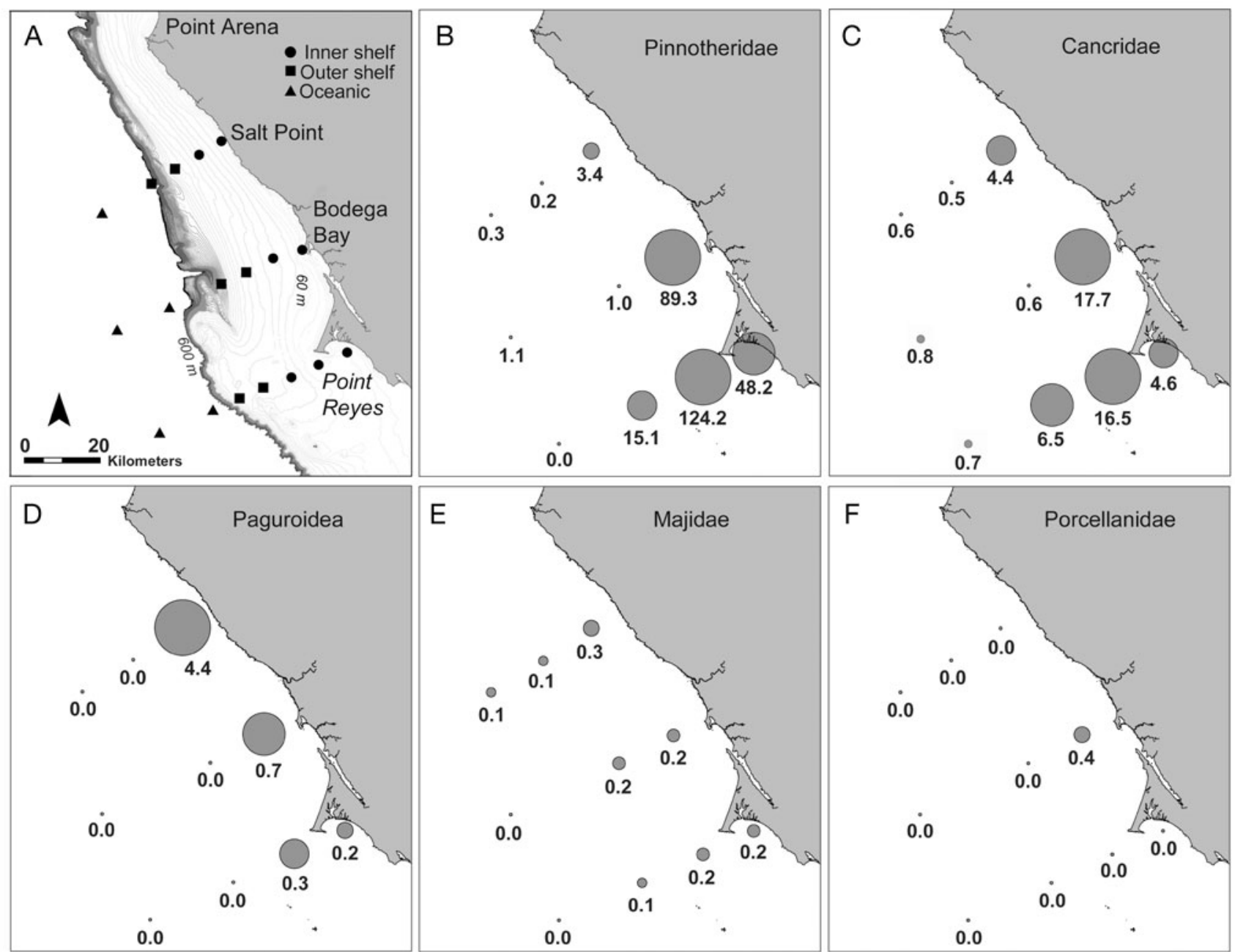

Fig. 1. Pinnotheridae, Cancridae, Paguroidea, Majidae, and Porcellanidae. Sampling stations and mean concentrations $\left(\mathrm{m}^{-2}\right)$ of crab postlarvae along 3 cross-shelf transects off Salt Point, Bodega Bay, and Point Reyes in northern California, USA. Sampling stations were classified as being located on the inner shelf (1 to $12 \mathrm{~km}$ from shore), outer shelf (20 to $30 \mathrm{~km}$ from shore), open ocean (40 to $70 \mathrm{~km}$ from shore), and lee of Point Reyes headland. Stations were sampled 8 times during the peak upwelling season (May and June) from 2000 to 2002. See Table 1 for sampling details. Note that the size of the circles is proportional to the maximum mean density of each taxon 
Table 1. Sampling dates, number of stations sampled along transects and during the daytime and nighttime, mean $( \pm 1$ SE) sea surface temperature (SST), and alongshore wind speed and classification of upwelling conditions for 8 cruises conducted off the coast of northern California, USA. Offshore SST and wind speed and direction were obtained from the National Data Buoy Center (NDBC 46013, 38 $13^{\prime} 30^{\prime \prime} \mathrm{N}, 123^{\circ} 19^{\prime} 00^{\prime \prime} \mathrm{W}$ ). Wind data were rotated in the alongshore direction to a principal axis of $349.4^{\circ}$ and filtered with a $36 \mathrm{~h}$ low-pass filter. Upwelling events were characterized by equatorward wind speeds greater than $5 \mathrm{~m} \mathrm{~s}^{-1}$, and relaxation conditions occurred when wind speeds were less than $3 \mathrm{~m} \mathrm{~s}^{-1}$

\begin{tabular}{|c|c|c|c|c|c|c|c|c|}
\hline \multirow[t]{2}{*}{ Sampling dates } & \multirow[b]{2}{*}{$\begin{array}{l}\text { Inner } \\
\text { shelf }\end{array}$} & \multicolumn{4}{|c|}{ Number of stations sampled- } & \multirow[t]{2}{*}{$\operatorname{SST}\left({ }^{\circ} \mathrm{C}\right)$} & \multirow{2}{*}{$\begin{array}{l}\text { Wind speed } \\
\qquad\left(\mathrm{m} \mathrm{s}^{-1}\right)\end{array}$} & \multirow[t]{2}{*}{ Classification } \\
\hline & & $\begin{array}{l}\text { Outer } \\
\text { shelf }\end{array}$ & $\begin{array}{l}\text { Open } \\
\text { ocean }\end{array}$ & Day & Night & & & \\
\hline 2-5 June 2000 & 4 & 4 & 5 & 6 & 7 & $9.9(0.2)$ & $-2.1(0.6)$ & Relaxation \\
\hline 17-20 June 2000 & 6 & 3 & 5 & 8 & 6 & $11.0(0.2)$ & $-0.7(0.5)$ & Relaxation \\
\hline 19-24 May 2001 & 4 & 3 & 4 & 3 & 8 & $10.4(0.1)$ & $-2.4(1.3)$ & Relaxation \\
\hline 3-10 June 2001 & 5 & 2 & 1 & 5 & 3 & $9.2(0.0)$ & $-9.1(0.5)$ & Upwelling \\
\hline 11-14 June 2001 & 7 & 3 & 3 & 8 & 5 & $9.2(0.1)$ & $-9.5(0.5)$ & Upwelling \\
\hline 31 May-1 June 2002 & 4 & 3 & 2 & 5 & 4 & $9.9(0.5)$ & $-7.7(3.6)$ & Upwelling \\
\hline 7-9 June 2002 & 3 & 2 & 0 & 5 & 0 & $8.2(0.0)$ & $-10.7(0.3)$ & Upwelling \\
\hline 15-17 June 2002 & 6 & 6 & 5 & 7 & 10 & $8.9(0.1)$ & $-8.4(0.3)$ & Upwelling \\
\hline Total & 39 & 26 & 25 & 47 & 43 & & & \\
\hline
\end{tabular}

the bottom was determined by comparing the reading of the pressure sensor on the net, which was continuously transmitted to the vessel via conducting cable, to the sonar reading of bottom depth aboard the research vessel. A maximal depth of $200 \mathrm{~m}$ was chosen to approximate the depth of the water column at the edge of the continental shelf. Ship speed was maintained at 2 knots while retrieving the nets at $10 \mathrm{~m} \mathrm{~min}^{-1}$. Both nets were fitted with flowmeters (General Oceanics ${ }^{\mathrm{TM}}$ model 2030) to determine the volume of water filtered, and larval densities were standardized to $\mathrm{m}^{-3}$ of water sampled. Samples were fixed in a buffered $10 \%$ formaldehyde-seawater solution, transferred to $70 \%$ ethanol, and subsampled using a 11 Folsom plankton splitter.

A large majority of crab postlarvae were identified to species or genus and the rest were identified to broader taxonomic levels. All postlarvae collected belonged to 4 families (Porcellanidae, Cancridae, Majidae, Pinnotheridae) and 1 superfamily (Paguroidea) of brachyuran and anomuran crabs. Adults from the family Porcellanidae were mostly Pachycheles spp., Petrolisthes cinctipes, and Petrolisthes eriomerus. The cancrids were mostly Cancer antennarius and C. magister; the majids were mostly Pugettia spp., the pinnotherids were mostly Fabia subquadrata; and the pagurids were mostly Pagurus samuelis, P. hirsuitiusculus, and P. granosimanus.

Cross-shelf distributions of postlarvae during each cruise were examined for each species and genus. They were similar within each family and superfamily, and data were combined for presentation and analysis. Sampling stations were categorized to determine whether postlarvae occurred primarily on the inner shelf, outer shelf, or open ocean. The shelf break occurs approximately $30 \mathrm{~km}$ from shore in our study region so the division between the inner and outer shelf is about $15 \mathrm{~km}$ from shore (Fig. 1). Sampling stations located 1 to $12 \mathrm{~km}$ from shore occurred on the inner shelf (including the Point Reyes headland), those located 20 to $30 \mathrm{~km}$ from shore occurred on the outer shelf, and those situated 40 to $70 \mathrm{~km}$ from shore occurred in the open ocean (Fig. 1). Larval concentrations (per $\mathrm{m}^{3}$ ) were multiplied by the depth of the water column and are presented per $\mathrm{m}^{2}$ to account for vertical dilution of postlarvae in the deepening water column across the continental shelf. The mean concentration of postlarvae is shown for each cross-shelf category and the area in the lee of Point Reyes to depict the prevalence of postlarvae across the study area. The single station in the lee of Point Reyes is a documented retention zone and is depicted separately from the group of stations sampled on the inner shelf. This unreplicated station provides an indication of the postlarval distributions between the lee of the headland and adjacent waters across the continental shelf, but additional sampling in the lee of the headland would have been needed to reliably test for differences among the areas.

Postlarvae of 2 taxa only occurred on the inner shelf, and the total numbers of postlarvae are depicted without analyzing them statistically, given that our primary objective was to determine their cross-shelf distributions. A 3-factor analysis of variance (ANOVA) was conducted to determine whether postlarvae of each of these 3 taxa occurred farther offshore (cross-shelf) during upwelling than relaxation conditions (wind) and farther off the Point Reyes headland compared to the other 2 locales (transect). To account for potential differences in larval production among years, the dependent variable for each taxon was the proportion of postlarvae per station within each year. Data were 
arcsine square-root transformed to meet assumptions of normality and homogeneity of variance. Crossshelf $\times$ wind interactions revealed whether postlarvae occurred farther offshore during upwelling than relaxation conditions, and cross-shelf $\times$ wind $\times$ alongshore interactions revealed whether postlarvae occurred farther offshore at Point Reyes during upwelling conditions. ANOVAs were followed by a Tukey-HSD multiple comparison test for the main factors without significant interaction terms.

We determined whether each of the 3 taxa occurring beyond the inner shelf were farther offshore during the 2 cruises that were conducted during upwelling conditions in 2001 or the 3 cruises that were conducted during upwelling conditions during 2002. A 2-factor ANOVA determined whether postlarval distributions within each year (year) and across the shelf (crossshelf) differed interannually (year $\times$ cross-shelf interaction). Larval densities were $\log _{10}(x+1)$-transformed to meet the assumptions of normality and homogeneity of variance.

Larval recruitment. Larval recruitment of crabs, barnacles, and mussels was monitored weekly throughout the peak upwelling season (15 May to 22 August) at 2 locations while cruises were being conducted in 2001 and 2002, and recruitment was related to interannual variation in upwelling. Larval recruitment was monitored weekly off Pinnacle Rocks in Bodega Bay and off the Bodega Marine Laboratory along the exposed coast of Bodega Head. Three moorings were spaced approximately $50 \mathrm{~m}$ apart along the $10 \mathrm{~m}$ isobath in sandy substrate adjacent to submerged rocks at each site. Standard settlement substrate was placed on each mooring $1 \mathrm{~m}$ below the surface and $1 \mathrm{~m}$ above the bottom. Settlement substrate for crabs and mussels consisted of 2 mesh bags $(10 \times 30 \mathrm{~cm})$ containing 3 Tuffy $^{\circledR}$ kitchen scrub pads each. Substrate for barnacles was a $10 \times 10 \mathrm{~cm}$ polyvinylchloride plate covered on both sides with black $3 \mathrm{M}^{\circledR}$ Safety Walk tape. Collectors were rinsed in fresh water, and recruits were preserved in $70 \%$ ethanol.

$\mathrm{Crab}$ recruits consisted of the same species that were most abundant during the plankton survey, and they were classified into the same taxonomic categories. However, pinnotherid postlarvae were not collected; they are commensal and unfortunately do not recruit to artificial collectors. Barnacle (Cirripedia) recruits were Chthamalus spp., Balanus glandua, B. crenatus, and Tetraclita rubescens. Mussel recruits likely consisted mostly of Mytilus californianus, although M. galloprovincialis and $M$. trossulus also occur far less abundantly on exposed coasts in the area. Data were combined for the 2 depths and 2 sites to test for differences in larval recruitment between 2001 and 2002. ANOVA was conducted for 5 taxa that met assumptions of normality and homogeneity of variance. A KruskalWallis test was conducted for 2 taxa that did not meet these assumptions (Cancridae, Mytilus spp.).

Upwelling conditions. The strength of upwelling conditions was determined for our study by obtaining mean daily values of the Bakun Coastal Upwelling Index (CUI: $\mathrm{m}^{3} \mathrm{~s}^{-1} 100 \mathrm{~m}^{-1}$ coastline) for our region $\left(39^{\circ} \mathrm{N}\right.$, $125^{\circ} \mathrm{W}$ ) from the Pacific Fisheries Environmental Laboratory (www.pfeg.noaa.gov). The CUI characterized the strength of upwelling conditions during the $3 \mathrm{wk}$ before the first cruise in each year to the end of the study period. We compared CUI values during our study to those obtained 3 wk before cruises that were conducted in central California $\left(36^{\circ} \mathrm{N}, 122^{\circ} \mathrm{W}\right)$ during a previous study on the effect of upwelling on larval advection offshore (Roughgarden et al. 1988). We also obtained the CUI beginning 1 mo before the recruitment study to the end of the study (15 April to 22 August) for each year and for the same time period during the preceding $5 \mathrm{yr}$. This period included a strong El Niño (1997-1998) and strong La Niña (1998-1999) providing a frame of reference.

\section{RESULTS}

The upwelling index was considerably greater during the 3 wk preceding all cruises in our study region (minimum of $112.6 \pm 24.5$ [SE] in 2000; maximum of $228.1 \pm 37.9$ in 2002) than for cruises conducted off central California in the 1970s and 1980s (exceeding $85 \mathrm{~m}^{3} \mathrm{~s}^{-1} 100 \mathrm{~m}^{-1}$ only once during $7 \mathrm{yr}$ ). The CUI was higher during the 3 wk preceding the 3 cruises conducted during upwelling in 2002 (193.3 \pm 33.3) compared to the 2 cruises conducted during upwelling in $2001(167.7 \pm 21.3)$. The CUI during the recruitment study was greater during 2002 (174.8 \pm 12.4) than 2001 (162.8 \pm 11.1 ; Fig. 2). CUIs during the $5 \mathrm{yr}$ preceding our study ranged from $110.7 \pm 8.7$ during the strong El Niño of 1997-98 and $184.5 \pm 12.2$ during the strong La Niña of 1999 (Fig. 2).

Of the 5 crab taxa collected, pinnotherid postlarvae were the most prevalent (7888) followed by cancrids (1776), pagurids (216), majids (56), and porcellanids (33). The large majority (84\%) of all postlarvae occurred on the inner shelf (Fig. 1). Postlarvae of pagurids and porcellanids occurred only on the inner shelf (Fig. 1). Most cancrid (77\%), pinnotherid (77\%), and majid ( $58 \%$ ) postlarvae also occurred on the inner shelf and declined with distance from shore (Fig. 1). Postlarvae of these 3 taxa along the southern transect appeared to be more prevalent on the inner shelf than in the lee of the headland.

Postlarvae of the 3 taxa that occurred beyond the inner shelf did not occur farther offshore during upwelling than during relaxation (Fig. 3, Table 2). 
Postlarval density of each taxon declined across the shelf during both upwelling and relaxation conditions, were prevalent during both upwelling and relaxation conditions, and were common across all 3 transects. Neither the cross-shelf $x$ wind nor cross-shelf $x$ wind $\times$ alongshore interaction terms were significant for any taxon, indicating that postlarvae did not occur farther offshore during upwelling conditions along any transect.

Postlarvae of the 3 taxa that occurred seaward of the inner shelf did not occur farthest from shore during the year of strongest upwelling (2002; Fig. 4). Cancrid and pinnotherid postlarvae declined with distance from shore overall (cross-shelf: Cancridae $F_{2,2}=3.7, \mathrm{p}=$ 0.03; Pinnotheridae $F_{2,2}=3.4, \mathrm{p}=0.04$ ) during cruises that were only conducted during upwelling conditions in 2001 and 2002, but this pattern was much less pronounced for majids (cross-shelf: $F_{2,2}=1.2, \mathrm{p}=0.30$ ). Postlarval densities were similar between years for all 3 taxa (year: Cancridae $F_{1,1}=1.6, p=0.22$; Pinno-

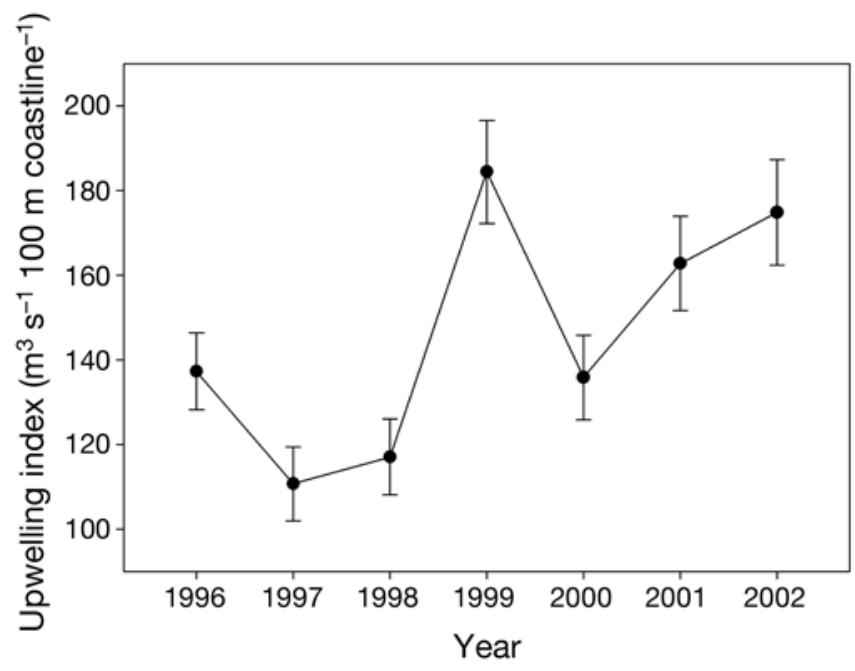

Fig. 2. Bakun upwelling index from 1996 to 2002 at $39^{\circ} \mathrm{N}$ latitude. Mean daily values $( \pm 1 \mathrm{SE}$ ) beginning 1 mo before the recruitment study to the end of the study (15 April to 22 August) are shown
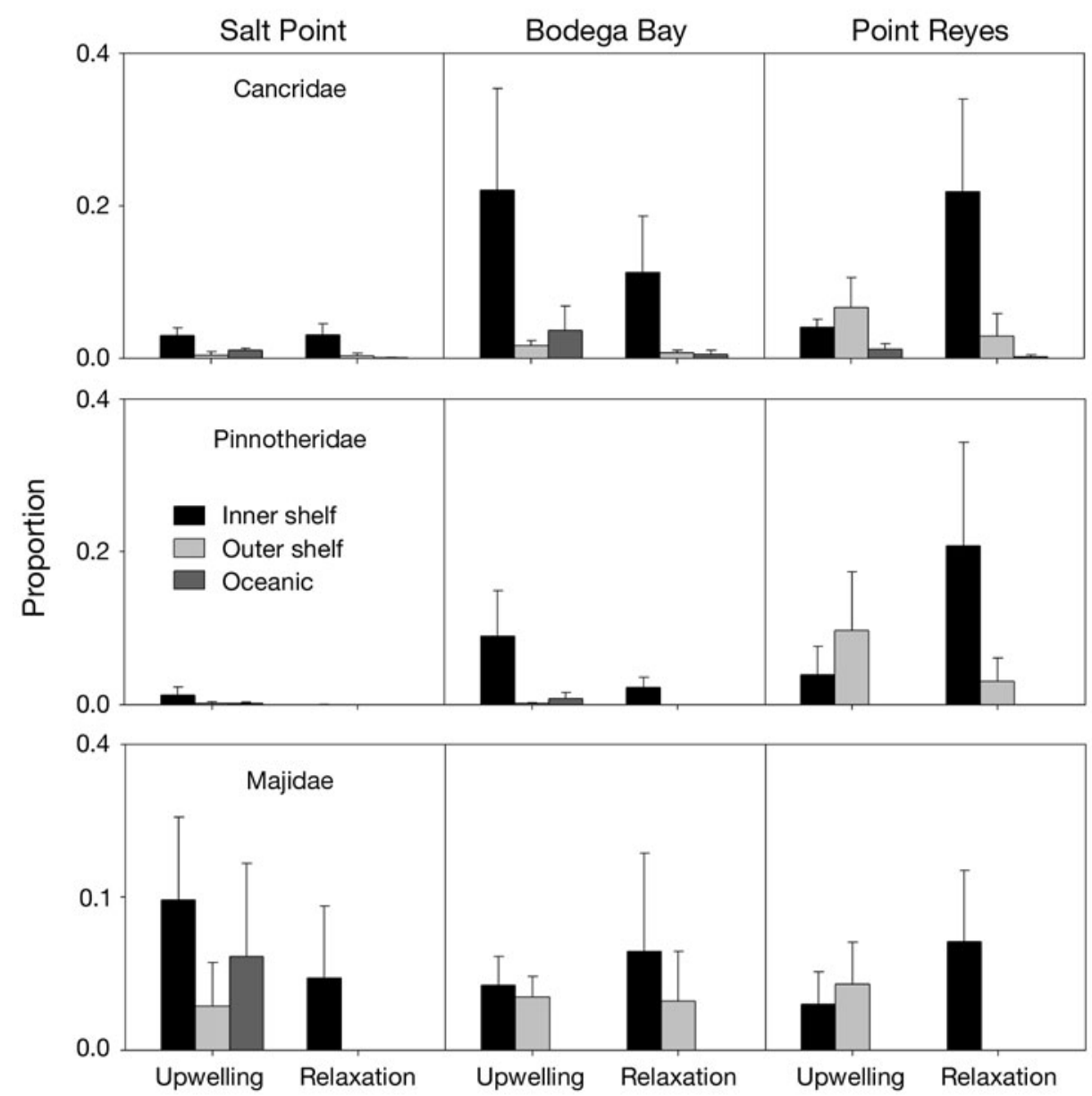

Fig. 3. Cancridae, Pinnotheridae, and Majidae. Cross-shelf distributions of crab postlarvae along transects off Salt Point, Bodega Bay, and Point Reyes, California, during upwelling and relaxation conditions. Data are presented for each taxon as the mean proportion (+1 SE) of postlarvae per station within each year 
Table 2. Cancridae, Pinnotheridae, and Majidae. Three-way ANOVA determining whether postlarvae occurred farther offshore (cross-shelf) during upwelling than during relaxation conditions (wind) and at the Point Reyes headland than at the other 2 locales (transect). The dependent variable was the proportion of postlarvae per station within each year to standardize for potential differences in larval production among years. Significant $(p<0.05)$ results are shown in bold

\begin{tabular}{|c|c|c|c|c|c|c|c|}
\hline \multirow[t]{2}{*}{ Source } & \multicolumn{3}{|c|}{ Cancridae } & \multicolumn{2}{|c|}{ - Pinnotheridae- } & \multicolumn{2}{|c|}{ Majidae } \\
\hline & $\mathrm{df}$ & $F$-ratio & $\mathrm{p}$ & F-ratio & $\mathrm{p}$ & F-ratio & $\mathrm{p}$ \\
\hline Wind (W) & 1 & 0.05 & 0.82 & 0.00 & 0.97 & 1.18 & 0.28 \\
\hline Cross-shelf (CS) & 2 & 10.75 & $<0.0001$ & 4.53 & 0.01 & 3.30 & 0.04 \\
\hline Transect $(\mathrm{T})$ & 2 & 1.85 & 0.16 & 2.53 & 0.09 & 0.28 & 0.76 \\
\hline $\mathrm{W} \times \mathrm{CS}$ & 2 & 1.48 & 0.24 & 0.57 & 0.57 & 0.45 & 0.64 \\
\hline $\mathrm{W} \times \mathrm{T}$ & 2 & 0.55 & 0.58 & 0.82 & 0.44 & 0.88 & 0.42 \\
\hline $\mathrm{CS} \times \mathrm{T}$ & 4 & 0.80 & 0.53 & 1.60 & 0.38 & 0.41 & 0.80 \\
\hline $\mathrm{W} \times \mathrm{CS} \times \mathrm{T}$ & 4 & 0.87 & 0.48 & 1.10 & 0.37 & 0.31 & 0.87 \\
\hline
\end{tabular}

theridae $F_{1,1}=0.00, \mathrm{p}=0.99$; Majidae $F_{1,1}=0.05, \mathrm{p}=$ 0.83 ), as were cross-shelf distributions (year $\times$ crossshelf: Cancridae $F_{2,2}=0.00, \mathrm{p}=0.99$; Pinnotheridae $F_{2,2}=0.60, \mathrm{p}=0.55 ;$ Majidae $\left.F_{2,2}=0.60, \mathrm{p}=0.55\right)$.

Postlarval recruitment did not generally decline in the year of strongest upwelling (Fig. 5). Recruitment was greater in the year of strongest upwelling (2002) than in the year of more moderate upwelling (2001) for 4 of the 7 taxa: Grapsidae, Paguroidea, Mytilus spp., and Cirripedia. It was greatest in the year of more moderate upwelling (2001) only for majids.

\section{DISCUSSION}

Larval distributions and recruitment of shallowwater crabs were not consistent with 4 tenets of the recruitment-limitation hypothesis. Few postlarvae were advected far from shore into the open ocean during the peak upwelling season in this region of strong upwelling and recruitment limitation. The large majority of all crab postlarvae (84\%) collected occurred on the inner shelf, and postlarvae were scarce off the shelf during both relaxation and upwelling conditions even at the windiest place along the west coast of the USA (Koracin et al. 2004). This pattern of maximal densities on the inner shelf was evident for postlarvae in 5 broad taxa that are known to disperse different distances from shore (Lough 1974). Porcellanids and pagurids occurred only on the inner shelf, whereas pinnotherids, cancrids, and majids often occurred on the outer shelf in low concentrations during our study as they did in the weaker upwelling conditions off Oregon (Lough 1974). Further, similar results were obtained during a subsequent 2 yr study of the cross-shelf distributions of crustacean larvae off Bodega Bay (Morgan et al. 2009). Thus, the cross-shelf distributions of crab postlarvae are consistent in time and space, even though postlarvae were predicted by the recruitment-limitation hypothesis to be transported farthest offshore by the strong Ekman transport in our region (Roughgarden et al. 1988). Previous studies (Yoshioka 1982, Roughgarden et al. 1988) were based on California Cooperative Oceanic Fisheries Investigations cruises that did not sample less than $8 \mathrm{~km}$ from shore where the maximal concentration of larvae occurs (Tapia \& Pineda 2007, Morgan et al. 2009). Consequently, the proportion of larvae advected offshore during upwelling may well have been overestimated.
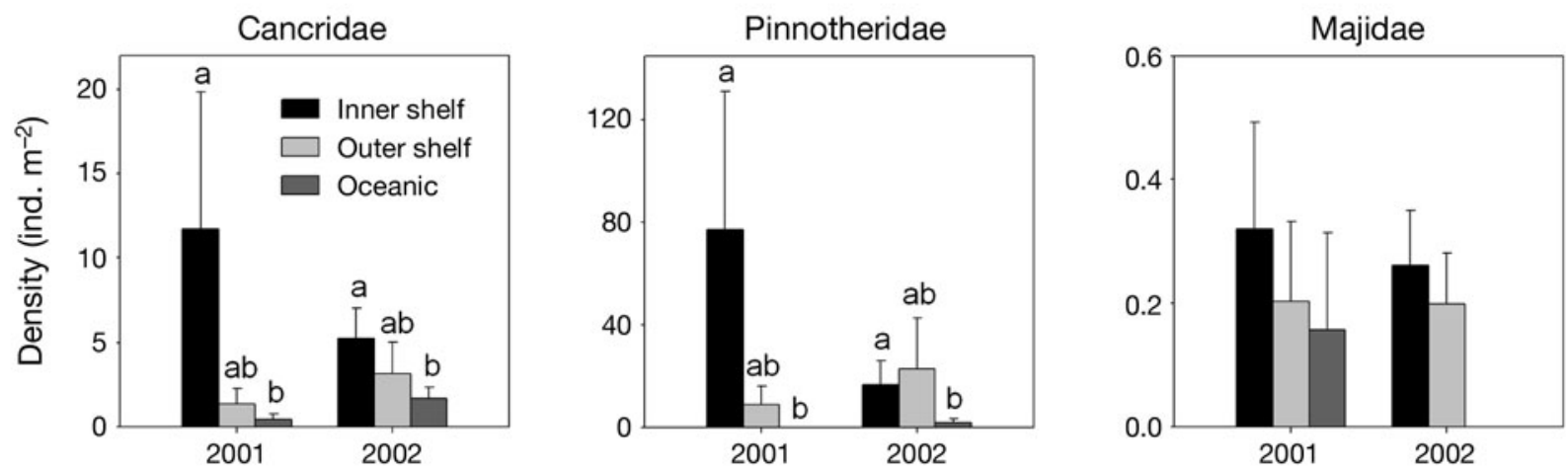

Fig. 4. Cancridae, Pinnotheridae, and Majidae. Cross-shelf distributions of crab postlarvae during cruises conducted during upwelling conditions in 2001 and 2002. Different letters indicate significant cross-shelf differences within years (Tukey HSD test, p < 0.05) 

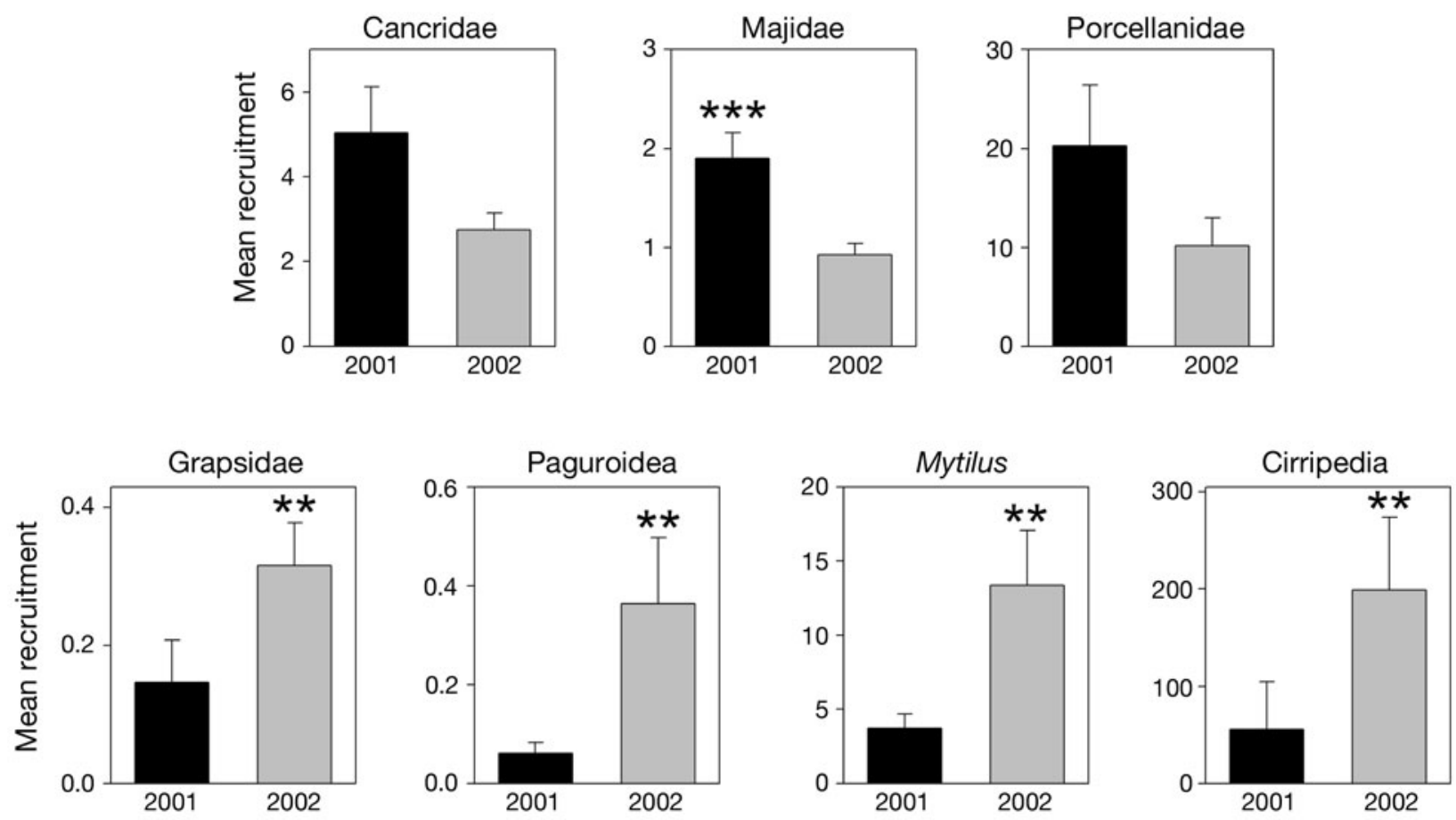

Fig. 5. Cancridae, Majidae, Porcellanidae, Grapsidae, Paguroidea, Mytilus spp., and Cirrpedia. Mean daily recruitment ( \pm 1 SE) for 7 taxa (crabs, mussels, barnacles) on moored artificial collectors from May to August during 2001 and 2002. Collectors were placed near the surface and bottom of the water column off Bodega Marine Laboratory at Bodega Head and off Pinnacle Rock in Bodega Bay and were collected weekly. Pinnotherids did not recruit to collectors. ${ }^{* *} \mathrm{p}<0.01,{ }^{* * *} \mathrm{p}<0.001$

Postlarvae did not occur farther from shore during upwelling than during relaxation conditions for any of the 5 taxa, nor did they occur father from shore during a year of very strong upwelling than during more moderate upwelling conditions. A large majority of postlarvae occurred on the inner shelf regardless of wind conditions, and the remainder largely occurred on the outer shelf shoreward of the upwelling front. The upwelling front during this study occurred over the outer shelf from 15 to $25 \mathrm{~km}$ from shore between the 100 and $200 \mathrm{~m}$ isobaths, separating newly upwelled waters on the shelf from warmer waters of the California Current (Roughan et al. 2006). The front was characterized by a distinct thermal and biomass boundary and different plankton assemblages occurring along each side of it, despite occasionally breaking down and reforming (Kudela et al. 2006, Lassiter et al. 2006, Papastephanou et al. 2006). The front was best developed and closest to shore in 2000, coinciding with weaker upwelling winds and more frequent relaxations, and it occurred farther offshore in 2001 and 2002 (Kudela et al. 2006, Roughan et al. 2006).

The recruitment-limitation hypothesis also predicts that larvae are swept far offshore at headlands where currents are deflected offshore in a coastal jet (Ebert \& Russell 1988, Kaplan \& Largier 2006), but we found limited support for this idea. Slightly more postlarvae of the 2 most abundant taxa (Pinnotheridae, Cancridae) occurred on the outer shelf at Point Reyes, but this tendency was not significant. Postlarvae of these 2 taxa were at least as prevalent at Point Reyes as at the other 2 study sites, and therefore it is unlikely that recruitment would be reduced at the headland.

Recruitment did not decline for most taxa during the year of stronger upwelling. To the contrary, postlarvae of most taxa recruited more during this year than the previous year of weaker upwelling. Although our recruitment study was conducted for only $2 \mathrm{yr}$, upwelling during the year that postlarvae of most taxa recruited was second only to the year of the strong La Niña for the $7 \mathrm{yr}$ period examined. Interspecific differences in annual recruitment of crabs could depend more on the timing of the onset of the upwelling season than the intensity of upwelling, but the onset of the upwelling season was similar during both years of our recruitment study (Shanks \& Roegner 2007). Lastly, recruitment during the year is not limited to infrequent relaxation events. We previously found that many of the same species of crabs that we studied here recruited abundantly in upwelling conditions, whereas only mussels recruited more abundantly during relaxation events (Mace \& Morgan 2006b, S. G. Morgan et al. unpubl.). Although our study was not consistent with the hypothesis that advection of crab postlarvae 
offshore during upwelling limits recruitment, this pattern could have been obscured by other factors that regulate larval production and survival, and additional studies may be warranted.

Interspecific differences in the cross-shelf distributions of postlarvae likely were maintained by regulating depth in the characteristic circulation of this upwelling region. The large majority of all postlarvae occurred on the inner shelf $<12 \mathrm{~km}$ from shore. This roughly coincides with the location of the coastal boundary layer, which occurs within $10 \mathrm{~km}$ from shore in our region (Largier et al. 1993, Kirincich et al. 2005, Kaplan \& Largier 2006, Roughan et al. 2006). A large majority of crab species complete larval development within the coastal boundary layer by remaining beneath the shallow Ekman layer, including most pinnotherids, porcellanids, and pagurids (Morgan et al. 2009). This feature of shoreline circulation (Pettigrew \& Murray 1986, Shanks 1995) likely contributes to the retention of crustacean larvae close to shore in the weaker upwelling conditions along the coasts of Oregon (Lough 1974), central California (Grantham 1997), and southern California (Tapia \& Pineda 2007). Larvae of other species migrated to the outer shelf by occurring closer to the surface early in development, including cancrids and majids (Morgan et al. 2009). These postlarvae mostly occurred shoreward of the upwelling front, which usually occurred from 15 to $25 \mathrm{~km}$ from shore on the outer shelf (Largier et al. 1993, Roughan et al. 2006). Postlarvae likely returned to nearshore adult habitats either by descending to shoreward-flowing upwelled waters or rising to the sea surface where they can be transported shoreward by relaxation events or internal waves (Pineda 1995, Shanks 1995, Grantham 1997). Natural selection may have favored simple larval behaviors that exploit conservative circulation patterns in upwelling regimes enabling larvae of different species to remain nearshore or migrate various distances offshore while limiting losses from advection. This has previously been well described for copepods (Peterson et al. 1979, Peterson 1998).

Postlarvae (pinnotherids, cancrids, majids) were more prevalent on the inner shelf adjacent to Point Reyes than in the recirculation feature in the lee of the headland. Although we only sampled 1 station in the lee of the headland, these findings are partly consistent with a previous study by Wing et al. (1998). They found that cancrid and pinnotherid postlarvae were more abundant in the lee of the headland than on the inner shelf during a cruise conducted in 1994 but not in 1995; postlarvae of intertidal crabs were at least as abundant on the inner shelf as in the lee of the headland during both years. Hence, entrainment of postlarvae in the coastal boundary layer may be as important as entrainment in the recirculation feature in the lee of headlands. This may partially explain why recruitment along the open coast poleward of headlands is not always limited to the propagation of currents delivering larvae from the lee of headlands during wind relaxations or reversals (Wing et al. 2003, Mace \& Morgan 2006b).

Other possible explanations for the interspecific differences in cross-shelf distributions of postlarvae are less likely. The pattern of high inshore concentrations of postlarvae in all taxa cannot be explained by dilution of postlarvae in deep waters, because larval concentrations were standardized by the depth of the water column. Further, all larval stages of most crab species occur close to shore, indicating that they complete development there (Morgan et al. 2009). Avoiding sampling near the bottom could have underestimated postlarvae if they were abundant there, but most postlarvae are concentrated in the upper mixed layer (Morgan et al. 2009). Alongshore dilution could have contributed to low concentrations of postlarvae found offshore, but the diverse taxa collected are widely distributed to the north and south of our sampling region. Postlarvae could as easily be advected into our region from adjacent waters as they could be out of our sampling region. Food availability should not have resulted in the cross-shelf decline in postlarvae, because higher nutrients and phytoplankton close to shore should support higher densities of larvae (Kudela et al. 2006, Wilkerson et al. 2006). More predators would also be supported by the high nearshore productivity, so that greater predation offshore is unlikely to account for the lower densities of larvae occurring there (Morgan 1990). The interspecific differences in cross-shelf distributions of postlarvae also are not due to differences in larval durations. The 3 taxa found only on the inner shelf do not all pass through fewer larval stages before molting to postlarvae (Porcellanidae: 2 stages; Paguroidea: 5) than the families that occurred farther offshore (Majidae: 2; Pinnotheridae: 5; Cancridae: 5; Morris et al. 1980). It is possible that postlarvae occurring beyond the inner shelf could have originated there for some species that range into deep waters as adults as opposed to being transported there by physically or behaviorally mediated processes. However, a subsequent study showed that the large majority of postlarvae developing on the inner shelf are from species that release larvae close to shore (Morgan et al. 2009).

The recruitment-limitation hypothesis has been very influential in developing our understanding of population dynamics and community structure in the sea, but key tenets do not appear to apply to crabs. Larval recruitment of most species studied thus far in this region of strong upwelling was not found to be limited 
to infrequent relaxation events (Mace \& Morgan 2006b, S. G. Morgan et al. unpubl.), and now we have shown that postlarvae of most species did not occur far offshore during strong upwelling. It is becoming increasingly apparent that larvae of a wide range of swimming capabilities remain close to shore throughout development in upwelling regions around the world, including mollusks (Poulin et al. 2002), barnacles (Grantham 1997, Tapia \& Pineda 2007, Morgan et al. 2009), crabs (Lough 1974, Queiroga et al. 2005, Marta-Almeida et al. 2006, dos Santos et al. 2008, Morgan et al. 2009), and fishes (Marliave 1986, Hernández-Miranda et al. 2003).

If larvae remain close to shore in upwelling regions, then it is unclear why these populations are limited by the number of recruiting postlarvae. Recruitment limitation could occur if larvae still occur too far from shore to recruit without being aided by infrequent relaxation events or internal waves (Pineda 1995, Shanks 1995). Settlement may also increase during relaxation when large breaking waves are less common and turbulence diminishes (Crimaldi et al. 2002). It also is possible that larvae have difficulty crossing the surf zone (Rilov et al. 2008). The extent and underlying mechanisms of recruitment limitation warrant close examination for a broader array of species. Comprehensive studies are needed to investigate the coupling of larval abundance in the plankton with settlement and postsettlement mortality on the shore to advance our understanding of processes that regulate marine populations and communities.

Acknowledgements. We thank members of the WEST group and the officers and crew of the RV 'Point Sur' for assistance in the field. This research was funded by the National Science Foundation (OCE-0326110 to S.G.M. and OCE-9908072 to S.M.B.) and is contribution number 2452 of the Bodega Marine Laboratory.

\section{LITERATURE CITED}

Batchelder HP, Edwards CA, Powell TM (2002) Individualbased models of copepod populations in coastal upwelling regions: implications of physiologically and environmentally influenced diel vertical migration on demographic success and nearshore retention. Prog Oceanogr 53: 307-333

Broitman BR, Navarrete SA, Smith F, Gaines SD (2001) Geographic variation of southeastern Pacific intertidal communities. Mar Ecol Prog Ser 224:21-34

Carr MH, Neigel JE, Estes JA, Andelman S, Warner RR, Largier JL (2003) Comparing marine and terrestrial ecosystems: implications for the design of coastal marine reserves. Ecol Appl 13(Suppl):90-107

Connolly SR, Menge BA, Roughgarden J (2001) A latitudinal gradient in recruitment of intertidal invertebrates in the northeast Pacific Ocean. Ecology 82:1799-1813

Crimaldi JP, Thompson JK, Rosman JH, Lowe RJ, Koseff JR (2002) Hydrodynamics of larval settlement: the influence of turbulent stress events at potential recruitment sites. Limnol Oceanogr 467:1137-1151

Dever EP, Dorman CE, Largier JL (2006) Surface boundary layer variability off northern California, USA, during upwelling. Deep-Sea Res II 53:2887-2905

dos Santos A, Santos AMP, Conway DVP, Bartilotti C, Lourenco P, Queiroga H (2008) Diel vertical migration of decapod larvae in the Portuguese coastal upwelling ecosystem: implications for offshore transport. Mar Ecol Prog Ser 359:171-183

Ebert TA, Russell AMP (1988) Latitudinal variation in size structure of the west coast purple sea urchin: a correlation with headlands. Limnol Oceanogr 33:286-294

Farrell TM, Bracher D, Roughgarden J (1991) Cross-shelf transport causes recruitment to intertidal populations in central California. Limnol Oceanogr 36:279-288

Frank KT, Leggett WC (1994) Fisheries ecology in the context of ecological and evolutionary theory. Annu Rev Ecol Syst 25:401-422

Gaines S, Roughgarden J (1985) Larval settlement rate: a leading determinant of structure in an ecological community of the marine intertidal zone. Proc Natl Acad Sci USA 82:3707-3711

Genin A, Jaffe JS, Reef R, Richter C, Franks PJS (2005) Swimming against the flow: a mechanism of zooplankton aggregation. Science 308:860-862

Grantham BA (1997) Coastal upwelling, larval recruitment, and the dynamics of upper intertidal barnacle communities. PhD dissertation, Stanford University, Stanford, CA

Grantham BA, Eckert GL, Shanks AL (2003) Dispersal potential of marine invertebrates in diverse habitats. Ecol Appl 13:108-116

Hernández-Miranda E, Palma AT, Ojeda FP (2003) Larval fish assemblages in nearshore coastal waters off central Chile: temporal and spatial patterns. Estuar Coast Shelf Sci 56: 1075-1092

Hickey B (1998) Coastal oceanography of western North America from the tip of Baja California to Vancouver Island. In: Robinson A, Brink KH (eds) The sea: ideas and observations on progress in the study of the seas. John Wiley \& Sons, New York, p 345-393

Hjort J (1914) Fluctuations in the great fisheries of northern Europe viewed in light of biological research. Rapp P-V Réun Cons Int Expl Mer 20:1-288

> Hobbs RC, Botsford LW (1992) Diel vertical migration and timing of metamorphosis of larvae of the Dungeness crab, Cancer magister, larvae. Mar Biol 112:417-428

Hutchings L, Beckley LE, Griffiths MH, Roberts MJ, Sundby S, van der Lingen C (2002) Spawning on the edge: spawning grounds and nursery areas around the southern African coastline. Mar Freshw Res 53:307-318

Kaplan DM, Largier JL (2006) HF radar derived origin and destination of surface waters off Bodega Bay, California. Deep-Sea Res II 53:2906-2930

Kirincich AR, Barth JA, Grantham BA, Menge BA, Lubchenco $\mathrm{J}$ (2005) Wind-driven inner-shelf circulation off central Oregon during summer. J Geophys Res 110(C10), C10S03, doi:10.1029/2004JC002611

Koracin D, Dorman CE, Dever EP (2004) Coastal perturbations of marine-layer winds, wind stress, and wind stress curl along California and Baja California in June 1999. J Phys Oceanogr 34:1152-1173

> Kudela RM, Garfield N, Bruland KW (2006) Bio-optical signatures and biogeochemistry from intense upwelling and relaxation in coastal California. Deep-Sea Res II 53: 2999-3022 
Lagos NA, Navarrete SA, Véliz F, Masuero A, Castilla JC (2005) Meso-scale spatial variation in settlement and recruitment of intertidal barnacles along the coast of central Chile. Mar Ecol Prog Ser 290:165-178

Largier JL, Magnell BA, Winant CD (1993) Subtidal circulation over the northern California shelf. J Geophys Res 98(C10):18147-18179

Lassiter AM, Wilkerson FP, Dugdale RC, Hogue VE (2006) Phytoplankton assemblages in the CoOP-WEST coastal upwelling area. Deep-Sea Res II 53:3063-3077

Lough R (1974) Dynamics of crab larvae (Anomura, Brachyura) off the Central Oregon Coast, 1969-1971. PhD dissertation, Oregon State University, Corvallis, OR

> Mace AJ, Morgan SG (2006a) Larval accumulation in the lee of a small headland: implications for the design of marine reserves. Mar Ecol Prog Ser 318:19-29

Mace AJ, Morgan SG (2006b) Biological and physical coupling in the lee of a small headland: contrasting transport mechanisms for crab larvea in an upwelling region. Mar Ecol Prog Ser 324:185-196

Marliave JB (1986) Lack of planktonic dispersal of rocky intertidal fish larvae. Trans Am Fish Soc 115:149-154

> Marta-Almeida M, Dubert J, Peliz Á, Queiroga H (2006) Influence of vertical migration pattern on retention of crab larvae in a seasonal upwelling system. Mar Ecol Prog Ser 307:1-19

Menge BA, Lubchenco J, Bracken MES, Chan F and others (2003) Coastal oceanography sets the pace of rocky intertidal community dynamics. Proc Natl Acad Sci USA 100:12229-12234

Menge BA, Blanchette C, Raimondi P, Freidenburg T and others (2004) Species interaction strength: testing model predictions along an upwelling gradient. Ecol Monogr 74:663-684

Morgan SG (1990) Impact of planktivorous fishes on the dispersal, hatching and morphology of estuarine crab larvae. Ecology 71:1639-1652

Morgan SG (1995) Life and death in the plankton: larval mortality and adaptation. In: McEdward L (ed) Ecology of marine invertebrate larvae. CRC Press, Boca Raton, FL, p 279-321

Morgan SG (2001) The larval ecology of marine communities. In: Bertness MD, Gaines SD, Hay ME (eds) Marine community ecology. Sinauer, Sunderland, MA, p 159-181

Morgan SG (2006) Larval migration between the Hudson River estuary and New York Bight. In: Levinton JS, Waldman J (eds) The Hudson River Estuary. Cambridge University Press, New York, p 157-170

Morgan SG, Fisher JL, Miller SH, McAfee ST, Largier J (2009) Nearshore larval retention in a region of strong upwelling and recruitment limitation. Ecology (in press)

Morris RH, Abbott DP, Haderlie EC (1980) Intertidal invertebrates of California. Stanford University Press, Stanford, CA

Papastephanou KM, Bollens SM, Slaughter AM (2006) Crossshelf distribution of copepods and the role of event-scale winds in a northern California upwelling zone. Deep-Sea Res II 53:3078-3093

Parrish RH, Nelson CS, Bakun A (1981) Transport mechanisms and the reproductive success of fishes in the California Current. Biol Oceanogr 1:175-203

> Peterson WT (1998) Life cycle strategies of copepods in coastal upwelling zones. J Mar Syst 15:313-326

Peterson WT, Miller CB, Hutchinson A (1979) Zonation and maintenance of copepod populations in the Oregon upwelling zone. Deep-Sea Res 26:467-494
Pettigrew NR, Murray SP (1986) The coastal boundary layer and inner shelf. In: Mooers CNK (ed) Barocline processes on continental shelves. American Geophysical Union, Washington, DC, p 95-108

Pineda J (1995) An internal tidal bore regime at nearshore stations along western U.S.A.: predictable upwelling within the lunar cycle. Cont Shelf Res 15:1023-1041

Poulin E, Palma AT, Leiva G, Narvaez D, Pacheco R, Navarrete SA, Castilla JC (2002) Avoiding offshore transport of competent larvae during upwelling events: the case of the gastropod Concholepas concolepas in central Chile. Limnol Oceanogr 47:1248-1255

> Queiroga H, Blanton J (2005) Interactions between behaviour and physical forcing in the control of horizontal transport of decapod crustacean larvae. Adv Mar Biol 47:107-214

> Queiroga H, Silva C, Sorbe JC, Morgado F (2005) Composition and distribution of zooplankton across an upwelling front on the northern Portuguese coast during summer. Hydrobiologia 545:195-207

Reilly PN (1983) Dynamics of Dungeness crab, Cancer magister, larvae off central and northern California. In: Wild PW, Tasto RN (eds) Life history, environment, and mariculture studies of the Dungeness crab, Cancer magister, with emphasis on the central California fishery resource. Calif Dep Fish Game Bull 172:57-84

Rilov G, Schiel DR (2006) Seascape-dependent subtidalintertidal trophic regulations. Ecology 87:731-744

Rilov G, Dudas SE, Menge BA, Grantham BA, Lubchenco J, Schiel DR (2008) The surf zone: a semi-permeable barrier to onshore recruitment of invertebrate larvae? J Exp Mar Biol Ecol 361:59-74

> Roughan M, Garfield N, Largier J, Dever E, Dorman C, Peterson D, Dorman J (2006) Transport and retention in an upwelling region: the role of across-shelf structure. DeepSea Res II 53:2931-2955

> Roughgarden J, Gaines SD, Possingham HP (1988) Recruitment dynamics in complex life cycles. Science 241: 1460-1466

Roughgarden J, Pennington JT, Stoner D, Alexander S, Miller K (1992) Collisions of upwelling fronts with the intertidal zone: the cause of recruitment pulses in barnacle populations of central California. Acta Oecol 12:35-51

Scheltema RS (1975) Chemistry, biology and the estuarine system. In: Crosonin LE (ed) Estuarine research, Vol 1. Academic Press, New York, p 372-391

Shanks AL (1995) Mechanisms of cross-shelf dispersal of larval invertebrates and fishes. In: McEdward L (ed) Ecology of marine invertebrate larvae. CRC, Boca Raton, FL, p 323-367

Shanks AL (2006) Mechanisms of cross-shelf transport of crab megalopae inferred from a time series of daily abundance. Mar Biol 148:1383-1398

Shanks AL, Brink L (2005) Upwelling, downwelling, and cross-shelf transport of bivalve larvae: test of a hypothesis. Mar Ecol Prog Ser 302:1-12

Shanks AL, Eckert GL (2005) Population persistence of California Current fishes and benthic crustaceans: a marine drift paradox. Ecol Monogr 75:505-524

Shanks AL, Roegner CG (2007) Recruitment limitation in Dungeness crab populations is driven by variation in atmospheric forcing. Ecology 88:1726-1737

Shenker JM (1988) Oceanographic associations of neustonic larval and juvenile fishes and Dungeness crab megalopae off Oregon. Fish Bull (Wash DC) 86:299-317

Strathmann MF (1987) Reproduction and development of marine invertebrates of the northern Pacific Coast. University of Washington Press, Seattle, WA 
Strathmann R, Hughes T, Kuris A, Lindeman K, Morgan S, Pandolfi J, Warner R (2002) Evolution of local recruitment and its consequences for marine populations. Bull Mar Sci 70:377-396

Tapia FJ, Pineda J (2007) Stage-specific distribution of barnacle larvae in nearshore waters: potential for limited dispersal and high mortality rates. Mar Ecol Prog Ser 342:177-190

Thorson G (1950) Reproductive and larval ecology of marine bottom invertebrates. Biol Rev Camb Philos Soc 25: $1-45$

Underwood AJ, Keough MJ (2001) Supply-side ecology: the nature and consequences of variations in recruitment of intertidal organisms. In: Bertness MD, Gaines SD, Hay ME (eds) Marine community ecology. Sinauer, Sunderland, MA, p 183-200

Wilkerson FP, Lassiter AM, Dugdale RC, Marchi A, Hogue VE (2006) The phytoplankton bloom response to wind events

Editorial responsibility: William Peterson,

Newport, Oregon, USA and upwelled nutrients during the CoOP-WEST Study. Deep-Sea Res II 53:3023-3048

Wing SR, Botsford L, Largier JL, Morgan LE (1995) Spatial structure of relaxation events and crab settlement in a northern California upwelling system. Mar Ecol Prog Ser 128:199-211

Wing SR, Botsford LW, Ralston JSV, Largier JL (1998) Meroplanktonic distribution and circulation in a coastal retention zone of the northern California upwelling system. Limnol Oceanogr 43:1710-1721

Wing SR, Botsford L, Morgan LE, Diehl JM, Lundquist CJ (2003) Inter-annual variability in larval supply to populations of three invertebrate taxa in the northern California Current. Estuar Coast Shelf Sci 57:859-872

Yoshioka PM (1982) Role of planktonic and benthic factors in the population dynamics of the bryozoan, Membranipora membranacea. Ecology 63:457-468

Young CM (1990) Larval ecology of marine invertebrates: a sesquicentennial history. Ophelia 32:1-48

Submitted: July 2, 2008; Accepted: December 30, 2008

Proofs received from author(s): March 20, 2009 